\title{
FORAGE YIELD AND QUALITY OF COMMON VETCH MIXTURES WITH TRITICALE AND ANNUAL RYEGRASS
}

\author{
Emine BUDAKLI CARPICI*, Necmettin CELIK \\ Uludag University, Faculty of Agriculture, Department of Field Crops, Bursa, TURKEY \\ *Corresponding author:ebudakli@uludag.edu.tr
}

Received: 08.01.2013

\begin{abstract}
The objective of this research was to determine the forage yield, quality and physiological properties of mixtures of common vetch (Vicia sativa $L$.) with triticale ( $\times$ Triticosecale Wittmack) and annual ryegrass (Lolium moltiflorum) grown as intermediate winter crop system under the conditions of Southern Marmara Region. Forage yield, light interception, leaf area index, crude protein content, crude protein yield, ADF and NDF contents were measured. The highest forage yield $(15.21 \mathrm{t} \mathrm{ha-1)}$ was obtained from $50 \%$ common vetch + $50 \%$ triticale mixture which was followed by $75 \%$ common vetch $+25 \%$ triticale, $25 \%$ common vetch $+75 \%$ triticale, $25 \%$ common vetch $+75 \%$ annual ryegrass mixtures. The results of two-year averages indicated that the $75 \%$ common vetch $+25 \%$ triticale mixturewas the best one for good quality and higher forage yield, and its suitability wasrecommended for the experimental ecology.
\end{abstract}

Keywords: annual ryegrass, common vetch, triticale, quality, intermediate winter crop

\section{INTRODUCTION}

Legumes and cereals do not provide satisfactory yields when they are pure seeded. There are some rational reasons of this situation. First of all, legume crops are low-yielding, especially in areas where rainfall is insufficient, and the plant lodging causes some problems during harvest. On the other hand, cereals produce high forage yields but with low protein content which is far from the requirements of many livestock (Rakeih et al., 2010). However, when legumes and cereals are combined in a mixture for forage production they exhibit good results.

Common vetch (Vicia sativa L.), an annual legume with climbing habit and high levels of protein, is usually grown in mixture with small grain annual cereals for forage production (Lithourgidis et al., 2006). Different cereals had been tested in mixtures with common vetch and the same or different results had been reported. The most proper cereals for mixture with common vetch were reported to be oat (Avena sativa L.) (Cabaollero and Goicoechea, 1986 and Thomson et al., 1990), barley (Hordeum vulgare L.) (Thompson et al., 1992 and Roberts et al., 1989), triticale (x Triticosecale Wittmack) (Anil et al., 1998). Sowing ratios in a mixture composed of legumes and cereals have yielded different results in different studies. Findings of Hasar and Tukel (1994) showed that $25 \%$ common vetch $+75 \%$ triticale mixture yielded more dry matter than other ratios of vetch-triticale mixtures. Turemen et al. (1990) reported that the highest dry matter yield was obtained from pure stand of annual ryegrass. Albayrak et al. (2004) found the highest dry matter and crude protein yields in the mixture including $70 \%$ hairy vetch $+30 \%$ triticale. Lithourgidis et al.(2006) evaluated pure sowings of common vetch, triticale and oat monocultures as well as mixtures of common vetch with the cereals in two seeding ratios $(55: 45$ and $65: 35)$ for forage yield and quality. They found that in all mixtures, the crude protein content increased as common vetch seeding proportion increased. Pure common vetch had the highest crude protein content. In contrast, triticale and oat pure sowings produced the lowest crude protein content. Kokten et al. (2009) reported that the mixture comprising $20 \%$ vetch and $80 \%$ triticale gave the highest dry matter yield with $23.5 \%$ vetch ratio under Adana conditions, while the mixture of $40 \%$ vetch $+60 \%$ triticale gave the highest dry matter yield with $10 \%$ vetch ratio under Kozan conditions in Turkey.

Research findings of above studies showed that more crude protein yield was obtained from the $80-90 \%$ vetch ratio. On account of protein content and yield, the vetchtriticale combination containing $90-80 \%$ vetch should be preferred to obtain high quality forage. In case of requirement of the forage containing high energy, the mixture containing higher triticale ratio could be preferred.

The objectives of the present study were to evaluate the pure stands of common vetch, triticale and annual ryegrass as well as the mixtures of common vetch with the 
mentioned cereals in different ratios (75:25, 50:50 and 25:75) for higher forage yield and quality, and to determine the proper mixture rates of vetch-cereal under rainfed conditions of Southern Marmara Region.

\section{MATERIALS AND METHODS}

Field studies were conducted during the 2009-2010 and 2010-2011 growing seasons on clay loam soil at the Agricultural Research and Experiment Center of Uludag University, Bursa $\left(40^{\circ} 11^{\prime} \mathrm{N}, 29^{\circ} 04^{\prime} \mathrm{E}\right)$. Soil test values indicated a $\mathrm{pH}$ of 7 , none saline, low values in lime and organic matter and rich in potassium. Precipitation distribution and amount differed markedly between the 2009-2010 and 2010-2011 growing seasons (Table 1). Total precipitation in $2009-2010$ was $236.8 \mathrm{~mm}$ over the long years and it resulted from higher precipitations fell in December, January, February and March of this year. Total precipitation in 2010-2011 growing season was 60.7 $\mathrm{mm}$ lower than that of the long years (Table 1). There were almost no differences between temperatures of experimental years and the long years.

Table 1. Monthly precipitation and temperature in 2009-2010, 2010-2011 and long years (1975-2008) in Bursa.

\begin{tabular}{|c|c|c|c|c|c|c|}
\hline \multirow[b]{2}{*}{ Months } & \multicolumn{3}{|c|}{ Monthly Precipitation (mm) } & \multicolumn{3}{|c|}{ Monthly Temperature $\left({ }^{\circ} \mathrm{C}\right)$} \\
\hline & Long Years & $2009-2010$ & $2010-2011$ & Long Years & $2009-2010$ & $2010-2011$ \\
\hline November & 85.4 & 80.6 & 24.0 & 10.3 & 10.1 & 15.5 \\
\hline December & 96.4 & 119.1 & 152.6 & 7.1 & 9.5 & 9.8 \\
\hline January & 80.3 & 149.7 & 72.4 & 5.4 & 7.0 & 5.6 \\
\hline February & 66.2 & 178.9 & 18.4 & 5.9 & 9.3 & 6.0 \\
\hline March & 62.7 & 115.3 & 67.4 & 8.5 & 9.0 & 8.3 \\
\hline April & 65.2 & 63.4 & 76.8 & 13.0 & 13.4 & 10.5 \\
\hline May & 43.4 & 29.4 & 27.3 & 17.7 & 19.2 & 16.7 \\
\hline Total & 499.6 & 736.4 & 438.9 & - & - & - \\
\hline Mean & - & - & - & 9.7 & 11.1 & 10.3 \\
\hline
\end{tabular}

In the experiment, common vetch (Vicia sativa L.) cv. Gulhan, triticale $(\times$ Triticosecale Wittmack) cv. Karma 2000 and annual ryegrass (Lolium multiflorum) cv. Caramba were used as plant materials. These species were sown as pure stands and mixtures. For mixtures, common vetch was combined with cereals in double combinations, and thus nine treatments were formed. Treatments were tested in a randomized complete block design with three replications. Plot size was $1.6 \times 5 \mathrm{~m}=8 \mathrm{~m}^{2}$ and seeded with eight rows. Seed amounts of species per hectare were based on the seed amounts of their pure sowings. The pure sowing rates of common vetch, triticale and annual ryegrass were 120,200 and $30 \mathrm{~kg} \mathrm{ha}^{-1}$, respectively. Seeding rate of a mixture was calculated by multiplying the seed amount of pure seeding of each species with its ratio in the mixture and the multiplication results of two species were summed. Mixtures were formed by combining vetch seed with those of cereals (triticale and annual ryegrass) in 75,50 and $25 \%$ ratios.

Sowings were made by hand on 15 November 2009 and 23 November 2010. Prior to sowing, $50 \mathrm{~kg} \mathrm{ha}^{-1} \mathrm{P}_{2} \mathrm{O}_{5}$ of $42-44 \%$ triple superphosphate and $30 \mathrm{~kg} \mathrm{ha}^{-1} \mathrm{~N}$ of $34 \%$ ammonium nitrate were applied as standard fertilizers.

Light interception values were determined using a LI SA191-A Quantum Sensor and were calculated according to the formula of Zaffaroni and Schneiter (1989) at the flowering stage of common vetch. At the same stage, leaf area indices were measured by LAI-2000 (LI-COR, Lincoln). Harvest was made at ground level when the lower pods of common vetches fully formed. After harvest, green forage samples were randomly taken from harvested green forages of each plot and put into cotton bags. Samples were oven-dried at $78{ }^{\circ} \mathrm{C}$ for 48 hours and weighed, then dry weight percentages were calculated. Forage yield of each plot was calculated by multiplying the fresh forage weight of each plot with its dry forage weight percentage. Oven-dried samples of plots were ground and $1 \mathrm{~g}$ samplewas used for the total nitrogen determination and $0.5 \mathrm{~g}$ for $\mathrm{ADF}$ and $\mathrm{NDF}$. $\mathrm{ADF}$ and NDF were analysed by sequential detergent analysis method (Goering and Van Soest, 1970) and total nitrogen by Kjedahl method (AOAC, 1984). Crude protein content was calculated by multiplying total nitrogen with 6.25 constant.

The whole data obtained were exposed to variance analysis at $1 \%$ and $5 \%$ significance level according torandomized complete block experimental design. For the differences among means of each parameter affected from treatments, the LSD test was used at 5\% significant level by using MINITAB and MSTAT-C programs.

\section{RESULTS AND DISCUSSION}

The forage yields averaged over-two year data were presented in Table 2. The highest forage yield (15.21 tha ${ }^{1}$ ) was obtained from $50 \%$ common vetch $+50 \%$ triticale mixture which was followed by $75 \%$ common vetch + $25 \%$ triticale, $25 \%$ common vetch $+75 \%$ triticale, $25 \%$ common vetch $+75 \%$ annual ryegrass mixtures. Yucel and Avci (2009) reported that mixture of common vetchtriticale (50:50) produced about 63\% more dry matter yield than pure sowing of common vetch, but about $12 \%$ less than that of pure triticale sowing. Numerous workers have determined different ratios for mixtures for maximum dry matter yield (Turemen et al., 1990; Hasar and Tukel, 1994; Albayrak et al., 2004; Kokten et al., 
2009; Yucel and Avci, 2009). These differences may be resulted from different ecological conditions, cultivars and

cropping systems.

Table 2. Forage yield (tons ha ${ }^{-1}$ ), light interception (\%) and leaf area index of pure and mixture seedings of common vetch, triticale and annual ryegrass (Two-year averages).

\begin{tabular}{lllll}
\hline Combinations of species & $\begin{array}{l}\text { Mixture } \\
\text { rate }\end{array}$ & $\begin{array}{l}\text { Forage yield } \\
\left(\text { tons ha }^{-1}\right)\end{array}$ & $\begin{array}{l}\text { Light interception } \\
(\%)\end{array}$ & $\begin{array}{l}\text { Leaf } \\
\text { area index }\end{array}$ \\
\hline Common vetch & 100 & $13.62 \mathrm{a}-\mathrm{d}$ & $94.7 \mathrm{a}$ & $7.5 \mathrm{ab}$ \\
Triticale & 100 & $12.53 \mathrm{~d}$ & $83.7 \mathrm{c}$ & $4.7 \mathrm{c}$ \\
Common vecth:Triticale & $75: 25$ & $14.48 \mathrm{ab}$ & $94.8 \mathrm{a}$ & $6.5 \mathrm{~b}$ \\
Common vecth:Triticale & $50: 50$ & $15.21 \mathrm{a}$ & $94.2 \mathrm{a}$ & $6.7 \mathrm{ab}$ \\
Common vecth:Triticale & $25: 75$ & $14.28 \mathrm{a}-\mathrm{c}$ & $89.3 \mathrm{~b}$ & $5.3 \mathrm{c}$ \\
Annual ryegrass & 100 & $9.56 \mathrm{e}$ & $82.1 \mathrm{c}$ & $5.4 \mathrm{c}$ \\
Common vecth:Annual ryegrass & $75: 25$ & $12.75 \mathrm{~cd}$ & $95.2 \mathrm{a}$ & $7.7 \mathrm{a}$ \\
Common vecth:Annual ryegrass & $50: 50$ & $13.56 \mathrm{~b}-\mathrm{d}$ & $95.3 \mathrm{a}$ & $7.5 \mathrm{ab}$ \\
Common vecth:Annual ryegrass & $25: 75$ & $13.95 \mathrm{a}-\mathrm{d}$ & $95.2 \mathrm{a}$ & $6.7 \mathrm{ab}$ \\
\hline
\end{tabular}

Means bearing by the same letter in a column were not significantly different at the $p<0.05$ level using the LSD test.

Light interception of species combinations indicated significant differences. All mixtures of common vetch with annual ryegrass, two mixtures of common vetch with triticale $(75 \%+25 \%$ and $50 \%+50 \%$ common vetch: triticale) and pure common vetch sowing intercepted light at the highest rate. The lowest light interceptions were realized at pure stands of cereals. Another important point was that the light interception in pure vetch stands was higher than those of cereals (Table 2).This result may be arisen from the higher leaf area index of common vetch than cereals. Stands of species combinations formed leaf area indices which were higher in pure stands of common vetch than in those of cereals. The combinations of common vetch with annual ryegrass yielded stands with greater leaf area indices when compared with those of common vetch-triticale combinations (Table 2).
Crude protein content is one of the most important criteria for fodder quality evaluation. The forage crude protein contents of the treatments varied greatly. The crude protein content of herbage of pure seeding vetch was the highest $(21.0 \%)$ among all herbages obtained from other stands. Pure triticale seeding produced herbage with the lowest crude protein content. When the ratio of common vetch in any mixture increased, so did the crude protein content of that mixture also (Table 3). Similar results have been reported by some researchers studied similar mixtures of cereals and legumes under intermediate winter crop system (Lithourgidis et al.,2006; Kokten et al., 2009; Yucel and Avci, 2009).

Table3. Crude protein content $(\%), \operatorname{ADF}(\%)$ and NDF $(\%)$ contents of pure and mixture of seedings common vetch, triticale and annual ryegrass (Two-year averages).

\begin{tabular}{lllll}
\hline Combinations of species & Mixture rate & $\begin{array}{l}\text { Crude protein } \\
\text { content }(\boldsymbol{\%})\end{array}$ & $\begin{array}{l}\text { ADF } \\
(\boldsymbol{\%})\end{array}$ & $\begin{array}{l}\text { NDF } \\
(\boldsymbol{\%})\end{array}$ \\
\hline Common vetch & 100 & $21.0 \mathrm{a}$ & $32.0 \mathrm{~d}$ & $55.0 \mathrm{bc}$ \\
Triticale & 100 & $6.9 \mathrm{f}$ & $41.7 \mathrm{a}$ & $65.5 \mathrm{a}$ \\
Common vecth:Triticale & $75: 25$ & $14.8 \mathrm{c}$ & $34.0 \mathrm{~cd}$ & $46.7 \mathrm{~d}$ \\
Common vecth:Triticale & $50: 50$ & $12.5 \mathrm{~d}$ & $38.8 \mathrm{~b}$ & $58.2 \mathrm{~b}$ \\
Common vecth:Triticale & $25: 75$ & $9.7 \mathrm{e}$ & $42.2 \mathrm{a}$ & $65.1 \mathrm{a}$ \\
Annual ryegrass & 100 & $8.3 \mathrm{ef}$ & $35.5 \mathrm{c}$ & $53.3 \mathrm{bc}$ \\
Common vecth:Annual ryegrass & $75: 25$ & $16.8 \mathrm{~b}$ & $33.5 \mathrm{~cd}$ & $54.7 \mathrm{bc}$ \\
Common vecth:Annual ryegrass & $50: 50$ & $15.4 \mathrm{bc}$ & $33.5 \mathrm{~cd}$ & $51.5 \mathrm{~cd}$ \\
Common vecth:Annual ryegrass & $25: 75$ & $12.0 \mathrm{~d}$ & $35.8 \mathrm{c}$ & $52.0 \mathrm{c}$ \\
\hline
\end{tabular}

Means bearing by the same letter in a column were not significantly different at the $p<0.05$ level using the LSD test.

ADF is an important criterion for quality forage, and it is expected to be present in low levels. In this study, the forages with low ADF content was produced by the pure stand of common vetch, designating high quality forage and followed by $75 \%$ common vetch $+25 \%$ triticale, $75 \%$ common vetch $+25 \%$ annual ryegrass and $50 \%$ common vetch $+50 \%$ annual ryegrass mixtures. Among all the sowings, the pure triticale stand and $25 \%$ common vetch + $75 \%$ triticale produced forages higher in ADF content (Table 3). Castro et al. (2000) and Yucel and Avci (2009) reported that increasing the ratio of triticale in a mixture increases\% ADF content of forage.

The results of the NDF values determined in the forages indicated differences among different sowing kinds. The lowest levels of NDF values were determined in the forages produced at $75 \%$ common vetch $+25 \%$ triticale mixture, while the pure triticale and $25 \%$ common vetch $+75 \%$ triticale mixture produced forages rich in NDF. Lithourgidis et al. (2006) reported that increasing the ratio of vetch in a mixture increases \% NDF ratio. 
These discrepancies can be attributable to the different cultivars, harvest stages, ecologies and agricultural systems in which the different studies were conducted.

\section{CONCLUSIONS}

This study was performed to determine the properintermediate winter crop system of common vetch combined with triticale and annual ryegrass in Southern Marmara Region and to attribute to the fodder problems and budget of livestock producers. For these purposes, common vetch and two annual cereals (triticale and annual ryegrass) were grown either in pure sowings or mixtures in different combinations such as 75:25, 50:50 and 25:75 (common vetch: cereals). The findings of twoyear research are as follows: (a) the highest forage yield $\left(15.21 \mathrm{t} \mathrm{ha}^{-1}\right)$ was produced from 50\% common vetch + $50 \%$ triticale mixture, (b) the highest light interception values were determined at pure stand of common vetch, $75 \%$ common vetch $+25 \%$ triticale, $50 \%$ common vetch $+50 \%$ triticale, $75 \%$ common vetch $+25 \%$ annual ryegrass, $50 \%$ common vetch $+50 \%$ annual ryegrass and $25 \%$ common vetch $+75 \%$ annual ryegrass mixtures, (c) the highest leaf area index was obtained from $75 \%$ common vetch $+25 \%$ annual ryegrass mixture, followed by pure stand of common vetch and $50 \%$ common vetch + $50 \%$ triticale, $50 \%$ common vetch $+50 \%$ annual ryegrass and $25 \%$ common vetch $+75 \%$ annual ryegrass mixtures, (d) forages of pure common vetch contained crude protein higher than those of all the other sowings, (e) crude protein contents of forages determined in pure triticale and annual ryegrass sowings were the lowest among all sowings and (f) triticale grown alone produced higher contents of ADF and NDF in its forages than the other sowings, indicating poor quality of forage.

In brief, as an overall evaluation, $75 \%$ common vetch $+25 \%$ triticale mixture can be recommended for quality and higher forage yield to be grown economically and safely under ecological condition of Southern Marmara Regionfor intermediate winter crop system

\section{ACKNOWLEDGEMENTS}

This research was supported by The Scientific Research Projects Unit of Uludag University (Project No: 2009/16, Project Leader: Dr. Emine Budakli Carpici). The author is grateful to The Scientific Research Projects Unit of Uludag University for financial support.

\section{LITERATURE CITED}

A O A C 1984 Official methods of analysis association of official agricultural chemists. 15th Ed:Washington D.C.

Albayrak, S.,M. Guler and M. O. Tongel, 2004. Effects of seed rates on forage production and hay quality of vetch-triticale mixtures. Asian Journal of Plant Sciences, 3 (6): 752-756.

Anil, L.,J. Park, R. H. Phipps and F. Miller, 1998. Temperate intercropping of cereal for forage: a review of potential for growth and utilization with particular reference to the UK. Grass and Forage Science. 53:301-317.

Caballero, R. and E. L. Goicoechea, 1986.Utilization of winter cereals as companion crops for common vetch and hairy vetch. Proceedings of the $11^{\text {th }}$ General Meeting of the European Grass Fed., 379-384.

Castro, M. P., F. Sau and J. Pineiro, 2000. Effect of seeding rates of oats (Avena sativa $\mathrm{L}$ ), wheat (Triticum aestivum $\mathrm{L}$.) and common vetch (Vicia sativa L.) on the yield, botanic composition and nutritive value of the mixture. CIHEAMOptions Mediterraneennes, pp. 207-211.

Goering, M.K. and P. J. Van Soest,1970. Forage fibre analysis. USDA Agricultural Handbook, USA,379,1-20.

Hasar, E. And T. Tukel, 1994. Effects of mixture rate and cutting times on forage yield, quality and seed yield of mixture components in mixtures ofvetch (Vicia sativa L.) andtriticale (Triticum $x$ Secale) grownthe lowland conditions of Cukurova. Field Crops Congress, 25-29 April 1994, vol. III:104-106, Izmir. In Turkish with English Abstract.

Kokten, K., F. Toklu,I. Atis and R. Hatipoglu, 2009. Effects of seeding rate on forage yield and quality of vetch (Vicia sativa L.) - triticale (Triticosecale Wittm.) mixtures under east mediterranean rainfed conditions. African Journal of Biotechnology, 8 (20):5367-5372.

Lithourgidis, A.S.,I. B. Vasilakoglou, K. V. Dhima, C. A. Dordas and M. D. Yiakoulaki,2006. Forage yield and quality of common vetch mixtures with oat and triticale in two seeding ratios. Field Crops Research 99:106-113.

Rakeih N., H. Kayya, A. Larb andN. Habib, 2010. Forage yield and competition indices of triticale and barley mixed intercropping with common vetch and grasspea in the Mediterranean Region. Jordan Journal of Agricultural Sciences, 6(2):194-207.

Roberts, C.A.,K. J. Mooreand K. D. Johnson, 1989. Forage quality and yield of wheat-common vetch at different stages of maturity and common vetch seeding rate. Agronomy Journal, 81: 57-60.

Thompson, D. J.,D. G. Stoutand T. Moore, 1992. Forage production by 4 annual cropping sequences emphasizing barley under irrigation in southern interior British Columbia. Canadian Journal of Plant Science, 72:181-185.

Thompson, E. F.,S. Rihawi and N. Nersoyan, 1990. Nutritive value and yields of some forage legumes and barley harvested as immature herbage, hay and straw in North-West Syria. Experimental Agriculture. 26:49-56.

Turemen, S.,T. Saglamtimur, V. Tansi and H. Baytekin, 1990. Performance of annual ryegrass and common vetch in association under different ratios. Cukurova University Journal of the Faculty Agric., 5 (1): 69-78.In Turkish with English Abstract.

Yucel, C. and M. Avci, 2009. Effect of different ratios of common vetch (Vicia sativa L.)-triticale (Triticosecale Whatt) mixtures on forage yields and quality in Cukurova plain in Turkey. Bulgarian Journal of Agricultural Science, 15(4): 323-332.

Zaffaroni, E. and P. J. Schneiter, 1989. Water-use efficiency and light interception of semi-dwarf and standard-height sunflower hybrids grown in different row arrangements. Agronomy Journal, 81:831-836. 